\title{
CORRIGENDUM
}

Genes \& Development 31: 674-687 (2017)

\section{Corrigendum: Dicer loss and recovery induce an oncogenic switch driven by transcriptional activation of the oncofetal Imp1-3 family}

Courtney K. JnBaptiste, Allan M. Gurtan, Kevin K. Thai, Victoria Lu, Arjun Bhutkar, Mei-Ju Su, Asaf Rotem, Tyler Jacks, and Phillip A. Sharp

While revisiting the acknowledgements for the above-mentioned article, we discovered that the names of two of our facility sponsors and one of the funding sources had been listed incorrectly and that the name of one of the facility sponsors had been omitted unintentionally. The errors have been corrected in both the PDF and full-text HTML files online.

doi: $10.1101 / \operatorname{gad} .302513 .117$ 


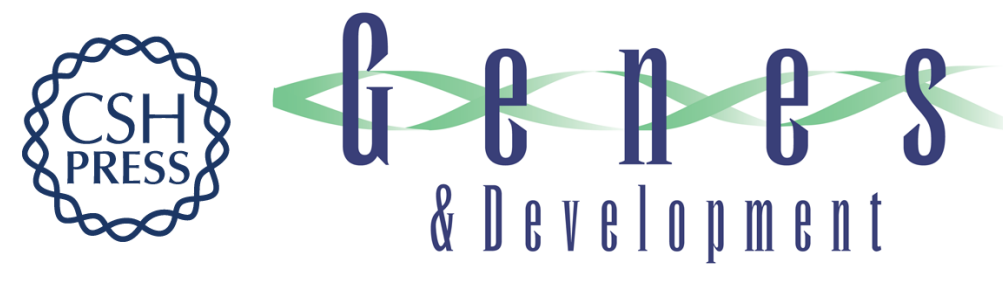

\section{Corrigendum: Dicer loss and recovery induce an oncogenic switch driven by transcriptional activation of the oncofetal Imp1-3 family}

Courtney K. JnBaptiste, Allan M. Gurtan, Kevin K. Thai, et al.

Genes Dev. 2017, 31:

Access the most recent version at doi:10.1101/gad.302513.117

Related Content Dicer loss and recovery induce an oncogenic switch driven by transcriptional activation of the oncofetal Imp13 family

Courtney K. JnBaptiste, Allan M. Gurtan, Kevin K. Thai, et al.

Genes Dev. April , 2017 31: 674-687

License

Email Alerting Receive free email alerts when new articles cite this article - sign up in the box at the top

Service right corner of the article or click here.

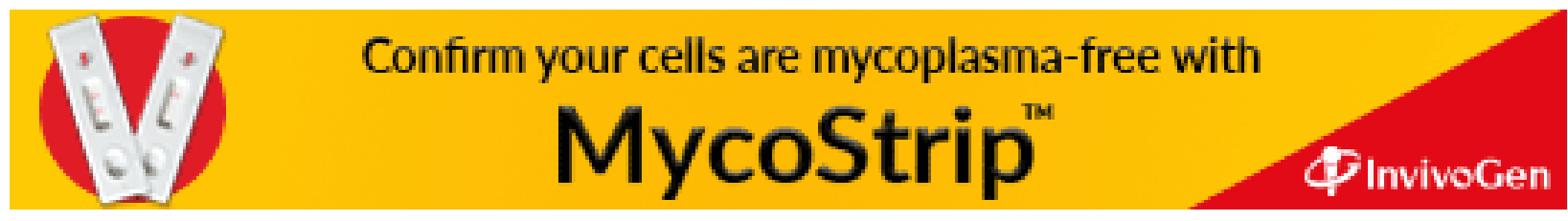

